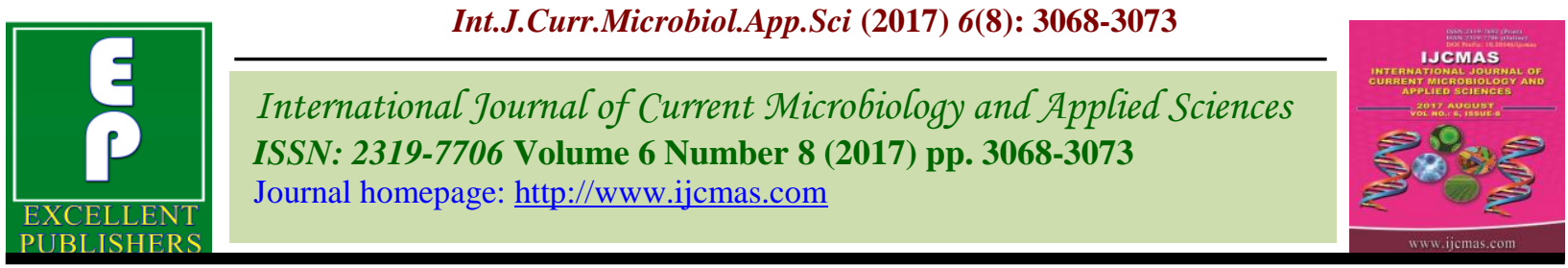

Original Research Article

https://doi.org/10.20546/ijcmas.2017.608.367

\title{
Marketing Behaviour of Glory Lily Growers
}

\author{
N. Suganthi ${ }^{1 *}$, P. Balasubramaniam ${ }^{1}$ and T.N. Sujeetha ${ }^{2}$ \\ ${ }^{1}$ Department of Agricultural Extension and Rural Sociology, TNAU, \\ Coimbatore- 641003, Tamil Nadu, India \\ ${ }^{2}$ Agricultural Extension and Rural Sociology, ADAC \& RI, Trichy-620 009, Tamil Nadu, India \\ *Corresponding author
}

\begin{tabular}{|l|l}
\hline \multicolumn{1}{c}{ A B S T R A C T } \\
\cline { 2 - 3 } $\begin{array}{l}\text { Keywords } \\
\text { Medicinal plant } \\
\text { growers, }\end{array}$ & $\begin{array}{l}\text { Medicinal plants gain significance because of their contribution to local health } \\
\text { support systems, generation of local income, foreign exchange earnings and } \\
\text { contribution to bio-diversity. Medicinal plants, if cultivated properly, it can } \\
\text { contribute significantly to the economic rural development. This study was } \\
\text { conducted in Dindigul district of Tamil Nadu, from the selected district four } \\
\text { Glory lily. }\end{array}$ \\
$\begin{array}{l}\text { villages was taken for the study. The medicinal plant selected for the study } \\
\text { purpose was Glory lily which is cultivated in Dindigul district of Tamil Nadu. } \\
\text { Regarding the export of medicinal plants India's contribution to the international } \\
\text { market is increasing rapidly (Kumar 2004). Utilizing our biodiversity with a } \\
\text { proper planning, Indian herbal products can very well enter the overseas markets. } \\
\text { 23 June 2017 } \\
\text { Available Online: } \\
\text { 10 August 2017 }\end{array}$ & $\begin{array}{l}\text { This can be achieved through increased cultivation of medicinal plants. At this } \\
\text { juncture, marketing behaviour of the medicinal plant growers was considered } \\
\text { important and analysed. The finding concluded that they existed low marketing } \\
\text { behaviour among the growers. }\end{array}$ \\
\hline \hline
\end{tabular}

\section{Introduction}

On the account of the fact that derivatives of medicinal plants have no side effects and deal curatively, the demand for these plants is on the increase in both developing and developed countries, as a result the trade for medicinal plants is increasing fast. The exports of medicinal plants contribute 9 per cent in the international market Baria (2002).

India has been a traditional exporter of medicinal plants for the past several decades and ranks one of the foremost suppliers of medicinal plants in the world. Though we are ranking second place in terms of export of medicinal plants, we rank only sixth position in terms of its value (Rajamani, 2004). The marketing of medicinal plants is inefficient, informal, secretive and opportunistic. As a result, the raw material supply situation is shaky, unsustainable and exploitative.

Hence the marketing behaviour of the respondents was studied, which includes mode of transport, place of sale, mode of sale, terms and condition for sale, selling pattern of farm produces, payment pattern, packing material used, opinion about existing market facilities, price etc., 


\section{Materials and Methods}

The study was conducted in Dindigul district of Tamil Nadu during the year 2012. Out of the 31 districts in Tamil Nadu, Dindigul districts of has been selected purposively for the study due to its area under medicinal plants cultivation is more while comparing other districts of Tamil Nadu.

In Tamil Nadu medicinal plants namely Coleus forskholii (Coleus), Gloriosa superba (Glory lily), Cassia angustifolia (senna), Catharanthus roseus (Periwinkle) are cultivated widely. For the study, it has been decided to take the top two medicinal plants that are cultivated in more than 1000 acres. Consequently, the medicinal plant Glory lily was cultivated in more area in Dindigul. Hence the district was purposively selected for the study.

There are fourteen blocks in Dindigul district, one block from each district namely, Thoppampatti was selected, because of the reason that the block had the maximum area under Glory lily cultivation. Out of 24 revenue villages of the block namely, Thoppampatti, four villages was selected. A sample size of 75 respondents was selected. Respondents were selected by using proportionate random sampling method.

The information to study the objective was collected by using the well-structured interview schedule. A pilot study was conducted in the non-sample area to pretest the schedule in order to test and verify the applicability of the schedule.

Percentage analysis was used for making simple comparison for calculating percentages for different items in their marketing behaviour. By using the cumulative frequency, their marketing behaviour was classified into low, medium, high.

\section{Results and Discussion}

Marketing behaviour referred to the capacity or tendency of an individual farmer to identify the market trend to sell the produce for greater returns.

In this study marketing behaviour was studied under different dimensions viz., mode of transport, place of sale, mode of sale, terms and condition for sale, selling pattern of farm produce, payment pattern, packing material used, opinion about existing market facilities, price etc.,

From table 1 it can be inferred, that the majority of the Glory lily respondents had low marketing behaviour $(73.00 \%)$ followed by medium and high $(17.00 \%$ and $10.00 \%)$ levels of marketing behaviour respectively.

The attributed reason for the low marketing behaviour among Glory lily respondents might be due to the involvement of intermediaries in the marketing channel, secretive trade, no proper market and unstable price.

The findings derive support from the findings of Ramasubramanian (2000).

\section{Place of sale}

From table 2, cent per cent $(100.00 \%)$ of the Glory lily respondents sold their produce in the village itself, as there is no proper market place to sell their produce, The contract firms/brokers could have involved in collecting the produce directly from the growers and this might be the reason for the result.

\section{Persons to whom sold}

It could be observed from table 2 , that cent per cent $(100.00 \%)$ of Glory lily respondents 
sold their produce to the brokers In case of Glory lily respondents as there is no contracts farming hence the brokers take the responsibility in collecting the produce from the farmer's field. The existence of secretive trade and the guidance provided by the contract officials and brokers with regard to marketing might be a reason for the above results.

\section{Terms and condition of sale}

It is revealed from table 2 that, cent per cent $(100.00 \%)$ of Glory lily respondents had sold their produce under the condition of ready cash payment. The reason could be the absence of contract farming and the sole dependence on brokers to sell their produce.

\section{Same/fluctuating price of the produce}

From table 2, shows that the, majority $(93.00 \%)$ of the Glory lily were unable to sell their produce for the same price throughout the year. The reason might be due to the ignorance of price of the produce among the respondents, fluctuation in the demand and price of product in the international market reason and more over they had believe the word of mouth of the brokers in relation to this.

\section{Time of sale}

It is observed from table 2, that, the majority (96.00\%) of the Glory lily growers sold the produce immediately after harvest and meager $(4.00 \%)$ of the Glory lily growers sold the produce when the price is attractive.

Here the economic part which is sold is the seed unless the seeds are properly shade and sun dried the moisture cannot be maintained hence after the harvest the seeds are collected by brokers and it is send to the traders for further process.

Table.1 Distribution of respondents according to their overall marketing behaviour

\begin{tabular}{|c|c|c|c|}
\hline \multirow{2}{*}{ S. No. } & \multirow{2}{*}{ Category } & \multicolumn{2}{|c|}{ Glory lily growers (n=75) } \\
\cline { 3 - 4 } & Low & No. & 73.00 \\
\hline 1. & Medium & 55 & 17.00 \\
\hline 2. & High & 13 & 10.00 \\
\hline 3. & Total & 7 & $\mathbf{1 0 0 . 0 0}$ \\
\hline
\end{tabular}

Table.2 Pattern of marketing behaviour of respondents

\begin{tabular}{|c|c|c|c|}
\hline \multicolumn{2}{|r|}{ Particulars } & \multicolumn{2}{|c|}{ Glory lily growers $(n=75)$} \\
\hline \multirow{5}{*}{1.} & \multicolumn{3}{|l|}{ Place of sale } \\
\hline & i. In the village itself & 75 & 100.00 \\
\hline & ii. Nearby town & - & - \\
\hline & iii. distant town (whole sale market) & - & - \\
\hline & Total & 75 & 100.00 \\
\hline \multirow[t]{8}{*}{ II. } & \multicolumn{3}{|l|}{ Persons to whom sold } \\
\hline & i)Brokers/middle men & 75 & 100.00 \\
\hline & ii)Consumers & - & - \\
\hline & iii)Practising Siddha doctors & - & - \\
\hline & iv)Exporters through commission agents & - & - \\
\hline & v)Traders through contract farming & - & - \\
\hline & vi) Company supplying material & - & - \\
\hline & vii)Society/NGO & - & - \\
\hline
\end{tabular}




\begin{tabular}{|c|c|c|c|}
\hline & viii)Exporters/wholesale traders directly & - & - \\
\hline & Total & 75 & 100.00 \\
\hline \multirow[t]{5}{*}{ III } & \multicolumn{3}{|l|}{ Terms and condition of sale } \\
\hline & i)Pre-harvest contract & 75 & 100.00 \\
\hline & ii)Deferred cash payment & - & - \\
\hline & iii)Ready cash payment & - & - \\
\hline & Total & 75 & 100.00 \\
\hline \multirow[t]{4}{*}{ IV } & \multicolumn{3}{|l|}{ Same/ fluctuating price } \\
\hline & i) Yes & 5 & 7.00 \\
\hline & ii)No & 70 & 93.00 \\
\hline & Total & 75 & 100.00 \\
\hline \multirow[t]{6}{*}{$\overline{\mathbf{V}}$} & \multicolumn{3}{|l|}{ Time of sale } \\
\hline & i)Immediately after harvest & 72 & 96.00 \\
\hline & ii)When in need of cash & - & - \\
\hline & iii)When it is convenient & - & - \\
\hline & iv)When price is attractive & 3 & 4.00 \\
\hline & Total & 75 & 100.00 \\
\hline \multirow[t]{4}{*}{ VI } & \multicolumn{3}{|l|}{ Grading of produce } \\
\hline & i)Yes & - & - \\
\hline & ii)No & 75 & 100.00 \\
\hline & Total & 75 & 100.00 \\
\hline \multirow[t]{6}{*}{ VII } & \multicolumn{3}{|l|}{\begin{tabular}{|l|} 
Price fixation of the produce \\
\end{tabular}} \\
\hline & i)Auction at market & - & - \\
\hline & $\begin{array}{l}\text { ii)Fixed price by buyers based on the demand in } \\
\text { the international markets }\end{array}$ & 75 & 100.00 \\
\hline & iii)Weight & - & - \\
\hline & iv)Grade & - & - \\
\hline & Total & 75 & 100.00 \\
\hline \multirow[t]{4}{*}{ VIII } & \multicolumn{3}{|l|}{ Disposal of the produce } \\
\hline & i)By/volume/weight & 75 & 100.00 \\
\hline & ii)Quality & - & - \\
\hline & Total & 75 & 100.00 \\
\hline \multirow[t]{6}{*}{ IX } & \multicolumn{3}{|l|}{ Packing materials used } \\
\hline & i. Nothing & - & - \\
\hline & ii. Gunny bags & 75 & 100.00 \\
\hline & iii. Polythene bags & - & - \\
\hline & iv. Wooden box & - & - \\
\hline & Total & 75 & 100.00 \\
\hline \multirow[t]{6}{*}{$\mathbf{X}$} & \multicolumn{3}{|l|}{ Mode of transport } \\
\hline & i. Head load & - & - \\
\hline & ii. Bicycle & - & - \\
\hline & iii. Bullock cart & 69 & 92.00 \\
\hline & vii. Tractor & 6 & 8.00 \\
\hline & Total & 75 & 100.00 \\
\hline \multirow[t]{5}{*}{ XI } & \multicolumn{3}{|l|}{ Opinion about existing market facilities } \\
\hline & i. Insufficient & 75 & 100.00 \\
\hline & ii. Sufficient & - & - \\
\hline & iii. Quite sufficient & - & - \\
\hline & Total & 75 & 100.00 \\
\hline \multirow[t]{5}{*}{ XII } & \multicolumn{3}{|l|}{ Opinion about the prevailing market price } \\
\hline & i)High & 5 & 7.00 \\
\hline & ii)Medium & 70 & 93.00 \\
\hline & iii)Low & - & - \\
\hline & Total & 75 & 100.00 \\
\hline
\end{tabular}




\section{Grading of produce}

According to the table 2, cent per cent of Glory lily respondents do not grade their produce this may due to the immediate disposal of produce after harvest and moreover the respondents do not have any facility to check the moisture level of their produce to be sold.

\section{Price fixation for the produce}

The results presented in table 2 , cent per cent of Glory lily respondents stated that the price was fixed by buyers based on the demand in the international markets. The demand and price for the produce will be always fluctuating and the price for the produce will not be known as like for the other produces.

\section{Disposal of produce}

It concluded from the table 2, that cent per cent of Glory lily respondents disposed their produce through weight; this might be felt as the easy way of measuring the bulk quantity of produce by the respondents, contract officials/brokers. Later from the traders, when the produce is ready for export the produce is checked for its quality. Quality here for Glory lily depends mainly on the moisture content which is difficult to maintain hence the produce is disposed.

\section{Packing material}

From the results depicted in table 2, it was noted that cent per cent of the Glory lily respondents used gunny bags for transporting the produce to the traders. Gunny bags may be easily available packing material to the villagers and more over they felt that the gunny bags permit free aeration inside because moisture content of the seeds are considered more important when it is exported, and moreover the economic part is the seed which can be easily packed in the gunny bags so all these could have been the contributing factors for the usage of gunny bags.

\section{Mode of transport}

Further, table 2, inferred that majority of the Glory lily respondents $(92.00 \%)$ used bullock cart and $(8.00 \%)$ of the used tractor as means of transport. The harvested produce are the seeds hence considering the size, cost of cheap means transport, the bullock cart may be selected by the brokers to transport the produce.

\section{Opinion on existing market facility}

The table 2, concluded that cent percent of the respondents stated that the marketing facility was insufficient for Glory lily respondents.

As mentioned earlier there is no market for selling the produce, unstable price, involvement of lot of intermediaries in the market channel, secretive trade may be the reason for insufficient market facility.

\section{Opinion on market price}

Table 2, indicates that majority of the respondents $(93.00 \%)$ of the Glory lily growers had medium opinion on the prevailing market price and (7.00) of Glory lily respondents had high opinion on the prevailing market price. The reason might be due to ignorance of price among respondents and fluctuating demand and price for the produce in the international market.

The findings of WHO (2002), reported that the global value of medicinal related trade in India is 5.5 billon US dollar and is growing rapidly. Further, the international market of herbal produce is estimated to be US\$ 62 billon which is poised to grow to US \$ 5 
trillion by the year 2050.To attain this stage we need to set right the negative markings. And since the marketing behaviour of the respondents is found to be low, this facility should be strengthened. Price forecast, avoidance of too many intermediaries in the market channel, formation of medicinal plant grower association may be few of the suggestion to overcome the problem.

\section{References}

Baria, B.G., 2002. Exploiting the potential of medicinal plants need for formulating action plan. Financing medicinal plants development (Special issue).Financing Agriculture, 34(3), 30-33.
Kumar, R., 2004. Medicinal, aromatic and herbal crops. Medicinal and aromatic plants in Uttaranchal (Special issue). Financing Agriculture, 36(3), 3-6.

Rajamani, K., 2004. Annual consumption rate of medicinal plants increased by fifteen per cent. Dinamani (Tamil Daily), p6

Ramasubramanian, M., 2000. A Study on Training Needs and Constraints Analysis in Mango Production. Unpub. M.Sc. (Ag.) Thesis, AC \& RI, TNAU, Madurai.

World health Organisation. 2002. Methodologies for Research and Evaluation of Herbal Medicines. Geneva, Switzerland: WHO.

\section{How to cite this article:}

Suganthi, N., P. Balasubramaniam and Sujeetha, T.N. 2017. Marketing Behaviour of Glory Lily Growers. Int.J.Curr.Microbiol.App.Sci. 6(8): 3068-3073. doi: https://doi.org/10.20546/ijcmas.2017.608.367 